\title{
The relationship between soil geochemistry and the bioaccessibility of trace elements in playground soil
}

\author{
Eduardo De Miguel · Juan Mingot • \\ Enrique Chacón · Susanne Charlesworth
}

\begin{abstract}
A total of 32 samples of surficial soil were collected from 16 playground areas in Madrid (Spain), in order to investigate the importance of the geochemistry of the soil on subsequent bioaccessibility of trace elements. The in vitro bioaccessibility of As, Co, Cr, $\mathrm{Cu}, \mathrm{Ni}, \mathrm{Pb}$ and $\mathrm{Zn}$ was evaluated by means of two extraction processes that simulate the gastric environment and one that reproduces a gastric + intestinal digestion sequence. The results of the in vitro bioaccessibility were compared against aqua regia extractions ("total" concentration), and it was found that total concentrations of $\mathrm{As}, \mathrm{Cu}, \mathrm{Pb}$ and $\mathrm{Zn}$ were double those of bioaccessible values, whilst that of $\mathrm{Cr}$ was ten times higher. Whereas the results of the gastric + intestinal extraction were affected by a high uncertainty, both gastric methods offered very similar and consistent results, with bioaccessibilities following the order: $\mathrm{As}=\mathrm{Cu}=\mathrm{Pb}=\mathrm{Zn}>\mathrm{Co}>$ $\mathrm{Ni}>\mathrm{Cr}$, and ranging from 63 to $7 \%$. Selected soil
\end{abstract}

properties including $\mathrm{pH}$, organic matter, $\mathrm{Fe}$ and $\mathrm{CaCO}_{3}$ content were determined to assess their influence on trace element bioaccessibility, and it was found that $\mathrm{Cu}, \mathrm{Pb}$ and $\mathrm{Zn}$ were predominantly bound to organic matter and, to a lesser extent, $\mathrm{Fe}$ oxides. The former fraction was readily accessible in the gastric solution, whereas Fe oxides seemed to recapture negatively charged chloride complexes of these elements in the gastric solution, lowering their bioaccessibility. The homogeneous $\mathrm{pH}$ of the playground soils included in the study does not influence trace element bioaccessibility to any significant extent except for $\mathrm{Cr}$, where the very low gastric accessibility seems to be related to the strongly $\mathrm{pH}$-dependent formation of complexes with organic matter. The results for As, which have been previously described and discussed in detail in Mingot et al. (Chemosphere 84: 1386-1391, 2011), indicate a high gastric bioaccessibility for this element as a consequence of its strong association with calcium carbonate and the ease with which these bonds are broken in the gastric solution. The calculation of risk assessments are therefore dependant on the methodology used and the specific environment they address. This has impacts on management strategies formulated to ensure that the most vulnerable of society, children, can live and play without adverse consequences to their health.

Keywords Bioaccessibility - Trace elements . Playground · Risk · Children · Urban 


\section{Introduction}

Children are exposed to toxic trace elements via a variety of means including ingestion with food and drink, inhalation of contaminated suspended particulates in the ambient air, direct ingestion of indoor dust in the home and school as well as outdoor street dust and soil from urban gardens. In those countries with a mild enough climate and where many of the population live in high rise buildings, children will make extensive use of formal play areas with an additional exposure pathway, that of any contaminated material deposited on outdoor playgrounds (for example, suspended particles in the urban aerosol, compost fertilised soil from adjacent gardens and lawns, miscellaneous litter). There have been several studies using risk assessments to consider the relevance of this exposure, concluding that ingestion of soil particles contributes most to overall risk (Dudka and Miller 1999). However, the use of such risk assessments raises problems; in that, the oral toxicity reference values commonly used (e.g. IRIS database, USEPA 2011) often owe their derivation to studies of human or animal populations in which the hazardous elements were administered in a soluble form (e.g. arsenic in drinking water: Tseng et al. 1968; Tseng 1977; chromium in drinking water: Zhang and Li 1987). This has led to values of $100 \%$ bioaccessibility (defined as the fraction of the trace element content which is dissolved in the gastro-intestinal tract and is available for transport across the intestinal lumen) and hence an over estimate of potential risk. However, contaminants found in association with soils are not $100 \%$ bioaccessible since they are not in solution but are bound to particulates in a variety of ways and depending on which the element will be released in the gastrointestinal tract to different extents. Therefore, whilst risk assessments based on the toxicity of soluble doses provide a more conservative protective evaluation, the use of bioaccessible concentrations offers a more realistic assessment of risk.

There are many in vitro studies of the bioaccessibility of trace elements in urban soils (Ljung et al. 2007; Madrid et al. 2008; Poggio et al. 2009; Rasmussen et al. 2008; Roussel et al. 2010). However, the results are variable and sometimes contradictory, and hence, there is little agreement. This is a reflection of the many and complex factors influencing the bioaccessibility of elements in a sample, including the geochemical specificity of the element of concern, its anthropogenic or natural origin, the granulometry and mineralogy of the sample, its organic carbon content, mode of retention, and so on. This variability of results also reflects the lack of standardisation of analytical methodologies used and certain difficulties associated with some techniques, in particular those attempting to reproduce conditions prevalent in both the human gastric and intestinal environments. Analytical difficulties associated with emulating these conditions include the need for long extraction times with large numbers of unstable reactants yielding concentrations near or below the detection limit. These problems have led to the development of simplified analytical protocols which address gastric-only conditions (e.g. Ruby et al. 1999) rather than methods seeking to replicate complete mouth-gastric-intestinal pathways (e.g. Oomen et al. 2003). The present paper follows on from the earlier work of Mingot et al. (2011), utilising both the two simplified standard protocols they used to evaluate trace element gastric bioaccessibility and the one which mimics the mouth-gastric-intestinal digestion pathway. Thus, the main aim of this study is an investigation of the influence of selected soil properties on the bioaccessibility of trace elements and hence, their potential impacts on children's health in urban environments.

\section{Materials and methods}

Two samples of approximately $500 \mathrm{~g}$ of surficial $(1-2 \mathrm{~cm})$ playground soil were collected in 16 playground sites within the municipality of Madrid with a plastic dust pan and brush and transferred to polyethylene bags for transport to the laboratory. The samples were oven dried at $45^{\circ} \mathrm{C}$ for $48 \mathrm{~h}$ and then sieved, in all-plastic sieving sets, through 2-mm, 500- $\mu \mathrm{m}$ and $100-\mu \mathrm{m}$ mesh. Details of the study sites and sample material are given in De Miguel et al. (2007). The fraction below $100 \mu \mathrm{m}$ was thoroughly homogenised and repeatedly quartered before four analytical samples were obtained. The remaining material was stored for determination of soil physicochemical properties and for use as an alternative sample if required.

The analytical samples were subjected to four different extraction protocols: 
1. The RIVM (Rijksinstituut voor Volksgezondheid en Milieu, Dutch Institute for Public Health and the Environment) method (Oomen et al. 2003) which simulates the digestive process in mouth, stomach and intestine: $9 \mathrm{~mL}$ of artificial saliva was added to $0.6 \mathrm{~g}$ of soil in centrifuge tubes and the mixture rotated for $5 \mathrm{~min}$ at $37{ }^{\circ} \mathrm{C}$. Subsequently, $13.5 \mathrm{ml}$ of gastric juice was added and the mixture rotated for $4 \mathrm{~h}$ at $37^{\circ} \mathrm{C}$. Afterwards, $36 \mathrm{ml}$ of intestinal juices $(27 \mathrm{ml}$ of duodenal juices and $9 \mathrm{ml}$ of bile) were added and the mixture rotated for $3 \mathrm{~h}$ and $30 \mathrm{~min}$ at $37{ }^{\circ} \mathrm{C}$. The mixture was centrifuged for $5 \mathrm{~min}$ at $3,000 \mathrm{grav}$ in order to separate the solid (pellets) and the liquid (chyme) fractions. $0.9 \mathrm{ml}$ of chyme was diluted with $8.1 \mathrm{ml}$ of $\mathrm{HNO}_{3} 2 \%$ for analysis. Details of the composition of artificial saliva, gastric juice and intestinal juices are presented in Oomen et al. (2003).

2. A simplified bioaccessibility extraction test (SBET) as described by Madrid et al. (2008): $0.5 \mathrm{~g}$ of soil was mixed with $50 \mathrm{ml}$ of glycine $0.4 \mathrm{M}$ at $\mathrm{pH}=1.5$ adjusted with $\mathrm{HCl}$, for $1 \mathrm{~h}$ at $37^{\circ} \mathrm{C}$. The mixture was centrifuged and the supernatant filtered using Whatman paper number 2.

3. A modified version of the European Standard Toy Safety Protocol EN-71 (European Committee for Standardization 1995) proposed by Rasmussen et al. (2008): $0.05 \mathrm{~g}$ of soil was mixed with $50 \mathrm{ml}$ of $\mathrm{HCl} 0.07 \mathrm{M}(\mathrm{pH}=1.5$ adjusted with $\mathrm{HCl})$ for $1 \mathrm{~h}$ at $37^{\circ} \mathrm{C}$. The mixture was left standing for an hour and then centrifuged and the supernatant filtered using Whatman paper number 2; and

4. An aqua regia extraction protocol, whose results were used as the reference to establish the bioaccessible ratio (i.e. per cent bioaccessibility) of trace elements: $0.5 \mathrm{~g}$ of soil was digested for $1 \mathrm{~h}$ in a hot water bath $\left(>95^{\circ} \mathrm{C}\right)$ with a $2: 2: 2$ mixture of $\mathrm{HCl}, \mathrm{HNO}_{3}$ and $\mathrm{H}_{2} \mathrm{O}$. After cooling, the solution was made up to $10 \mathrm{~mL}$ with $5 \% \mathrm{HCl}$. The concentration of trace and major elements was determined by inductively coupled plasmamass spectrometry (ICP-MS). Method detection limits were $0.1 \mathrm{mg} \mathrm{Kg}^{-1}$ for $\mathrm{Co}, \mathrm{Cu}, \mathrm{Ni}$ and $\mathrm{Pb}$, $0.5 \mathrm{mg} \mathrm{Kg}^{-1}$ for As and $1 \mathrm{mg} \mathrm{Kg}^{-1}$ for $\mathrm{Cr}$ and $\mathrm{Zn}$.

Quality controls consisted of five sample triplicates and one blank triplicate for each batch of 32 samples as well as analysis in triplicate of certified reference material STD DS6 (Acme Analytical Laboratories), for the aqua regia extraction, and in duplicate of certified reference material WEPAL ISE 987 (Wageningen University), for the rest of the determinations (including physicochemical properties). The relative standard deviation of the replicates was below $10 \%$ for all elements. Average recovery rates for the aqua regia extraction ranged from $96.7 \%$ for $\mathrm{Pb}$ to $99.8 \%$ for $\mathrm{Cu}$. The WEPAL ISE 987 reference material is not certified for bioaccessible concentrations, but it was nonetheless extracted and analysed according to the three protocols previously described. Bioaccessibility ratios, relative to the aqua regia certified values, were consistent with those obtained in this study and ranged between $9 \%$ (RIVM), $4 \%$ (SBET) and $10 \%$ ( $\mathrm{HCl}$ extraction) for $\mathrm{Cr}$, and $74 \%$ (RIVM), $77 \%$ (SBET) and $89 \%$ (HCl extraction) for As.

The determination of the physico-chemical properties was carried out in duplicate on the $<100 \mu \mathrm{m}$ size fraction: Soil $\mathrm{pH}$ and electrical conductivity were measured in $1: 2$ and 1:5 soil/water extracts, respectively, oxidisable organic matter content was determined using the Walkley-Black method (Walkley 1935), calcium carbonate was determined with the calcimeter Bernard method (Allison and Moodie 1965), and cation exchange capacity was evaluated with $1 \mathrm{~N}$ ammonium acetate (Bower et al. 1952). Analyses of the WEPAL ISE 987 standard yielded results that were 116,102 and $90 \%$ of the certified values for oxidisable organic matter, $\mathrm{pH}$ and calcium carbonate, respectively.

Statistical analyses were carried out using R ( R Development Core Team 2004).

\section{Results and discussion}

Tables 1 and 2 show descriptive statistics for all analysed parameters. Aqua regia concentrations of As, $\mathrm{Co}$ and $\mathrm{Ni}$ in Madrid playgrounds are similar to regional background values, $\mathrm{Cr}$ and $\mathrm{Pb}$ concentrations are $50 \%$ higher, and $\mathrm{Cu}$ and $\mathrm{Zn}$ duplicate their baseline levels (De Miguel et al. 2002). With a relative standard deviation of $4 \%$, samples exhibited a very uniform basic $\mathrm{pH}$ of approximately 8.5 ; oxidisable organic matter $(\mathrm{OM})$ was more variable and generally low with $78 \%$ of the results $<3 \%$. Total $\mathrm{Fe}$ and $\mathrm{Ca}$ contents show median values of 1 and $1.3 \%$, respectively, with 
Table 1 Results of aqua regia concentrations $\left(\mathrm{mg} \mathrm{Kg}^{-1}\right.$ ) and bioaccessibility (as \% of aqua regia-extractable concentration) following three extraction tests

\begin{tabular}{|c|c|c|c|c|c|c|c|c|}
\hline Extraction & Element & No. samples & Mean & Median & Std. Dev. & Rel. Std. Dev. (\%) & Max. & Min. \\
\hline \multirow[t]{7}{*}{ Aqua regia } & As & 32 & 6.8 & 6.4 & 1.6 & 23 & 12 & 4.4 \\
\hline & Co & 32 & 3.8 & 3.8 & 0.85 & 23 & 5.4 & 2.3 \\
\hline & $\mathrm{Cr}$ & 32 & 23 & 20 & 10 & 45 & 53 & 9.9 \\
\hline & $\mathrm{Cu}$ & 32 & 21 & 19 & 11 & 50 & 58 & 8.7 \\
\hline & $\mathrm{Ni}$ & 32 & 8.2 & 8.1 & 3.0 & 36 & 18 & 4 \\
\hline & $\mathrm{Pb}$ & 32 & 26 & 22 & 15 & 55 & 66 & 10 \\
\hline & $\mathrm{Zn}$ & 32 & 82 & 66 & 49 & 60 & 282 & 33 \\
\hline \multirow[t]{7}{*}{$\mathrm{HCl}$} & As & 31 & 54 & 53 & 9.3 & 17 & 75 & 37 \\
\hline & Co & 31 & 29 & 31 & 9.7 & 33 & 43 & 13 \\
\hline & $\mathrm{Cr}$ & 31 & 7.8 & 7.2 & 4.1 & 53 & 19 & 2.8 \\
\hline & $\mathrm{Cu}$ & 31 & 52 & 52 & 29 & 56 & 116 & 7.3 \\
\hline & $\mathrm{Ni}$ & 31 & 20 & 19 & 11 & 54 & 50 & 6.4 \\
\hline & $\mathrm{Pb}$ & 31 & 53 & 53 & 16 & 31 & 82 & 25 \\
\hline & $\mathrm{Zn}$ & 31 & 48 & 45 & 18 & 38 & 82 & 21 \\
\hline \multirow[t]{7}{*}{ SBET } & As & 32 & 62 & 64 & 13 & 20 & 87 & 39 \\
\hline & Co & 32 & 26 & 25 & 6.4 & 24 & 39 & 14 \\
\hline & $\mathrm{Cr}$ & 32 & 6.4 & 4.8 & 4.3 & 67 & 18 & 2.0 \\
\hline & $\mathrm{Cu}$ & 32 & 46 & 46 & 8.9 & 19 & 66 & 30 \\
\hline & $\mathrm{Ni}$ & 32 & 20 & 17 & 7.5 & 38 & 37 & 9.1 \\
\hline & $\mathrm{Pb}$ & 32 & 59 & 56 & 15 & 26 & 95 & 38 \\
\hline & $\mathrm{Zn}$ & 32 & 47 & 48 & 14 & 30 & 92 & 25 \\
\hline \multirow[t]{7}{*}{ RIVM } & As & 32 & 43 & 42 & 6.6 & 16 & 59 & 33 \\
\hline & Co & 32 & 63 & 63 & 12 & 19 & 85 & 43 \\
\hline & $\mathrm{Cr}$ & 31 & 40 & 39 & 18 & 45 & 81 & 5.0 \\
\hline & $\mathrm{Cu}$ & 29 & 61 & 61 & 23 & 37 & 99 & 25 \\
\hline & $\mathrm{Ni}$ & - & - & - & - & - & - & - \\
\hline & $\mathrm{Pb}$ & 24 & 57 & 62 & 30 & 53 & 103 & 4.0 \\
\hline & $\mathrm{Zn}$ & 32 & 46 & 46 & 12 & 26 & 69 & 25 \\
\hline
\end{tabular}

$\mathrm{CaCO}_{3}$ ranging from 1.7 to $7.2 \%$, with a median value of $2.6 \%$. Compared to similar studies of urban soils which report soil properties, the samples from Madrid playgrounds are OM- and Fe-deficient and have a significantly higher pH (e.g. Juhasz et al. 2007; Ljung et al. 2007; Poggio et al. 2009; Rasmussen et al. 2008; Roussel et al. 2010; Yang et al. 2002).

Assuming constant variance of residuals and zero bioaccessibility at zero total concentration, the percentage of gastric and gastric + intestinal bioaccessibility was established as the slope of a linear regression intercepting the origin of $\mathrm{SBET}, \mathrm{HCl}$ and RIVM concentrations versus the total concentrations of each element. The bioaccessibility ratios thus estimated for $\mathrm{As}, \mathrm{Co}, \mathrm{Cr}, \mathrm{Cu}, \mathrm{Ni}, \mathrm{Pb}$ and $\mathrm{Zn}$ and for the three extraction methods are shown in Table 3 ("slope") except for RIVM Ni, which was removed since a third of all results were below the detection limit. Correlations between bioaccessible and total concentrations were highly significant for all elements except $\mathrm{HCl} \mathrm{Ni}$ ( $p$ value: 0.21 ) and SBET Cr ( $p$ value: 0.02 ) and quite robust as indicated by the confidence intervals of the linear regressions (Table 3 ).

As shown in Table 3, the results of SBET and $\mathrm{HCl}$ bioaccessibility percentages were almost identical for all elements (relative differences between the results of both methods are $<15 \%$ ), except for As $(19.6 \%)$ and $\mathrm{Cr}(31.6 \%)$. Arsenic, $\mathrm{Cu}, \mathrm{Pb}$ and $\mathrm{Zn}$ have similar gastric bioaccessibility percentages of between 48 and $63 \%$. Cobalt and Ni exhibit bioaccessibilities that are 
Table 2 Soil properties and concentration of major elements in samples from playground surface soil

\begin{tabular}{|c|c|c|c|c|c|c|c|}
\hline & No. samples & Mean & Median & Std. Dev. & Rel. Std. Dev. (\%) & Max. & Min. \\
\hline $\mathrm{Fe}(\%)$ & 32 & 1.03 & 1.00 & 0.23 & 22 & 1.43 & 0.66 \\
\hline $\mathrm{Ca}(\%)$ & 32 & 2.10 & 1.35 & 1.91 & 91 & 8.53 & 0.47 \\
\hline $\mathrm{P}(\%)$ & 32 & 0.068 & 0.056 & 0.045 & 66 & 0.254 & 0.038 \\
\hline $\operatorname{Mg}(\%)$ & 32 & 0.32 & 0.32 & 0.09 & 28 & 0.63 & 0.16 \\
\hline $\mathrm{Ti}(\%)$ & 32 & 0.023 & 0.022 & 0.006 & 28 & 0.042 & 0.012 \\
\hline $\mathrm{Al}(\%)$ & 32 & 0.84 & 0.78 & 0.23 & 27 & 1.31 & 0.45 \\
\hline $\mathrm{Na}(\%)$ & 32 & 0.013 & 0.010 & 0.007 & 56 & 0.033 & 0.006 \\
\hline K $(\%)$ & 32 & 0.24 & 0.21 & 0.08 & 33 & 0.42 & 0.14 \\
\hline $\operatorname{Mn}(\%)$ & 32 & 0.028 & 0.027 & 0.008 & 29 & 0.048 & 0.015 \\
\hline Organic matter $(\%)$ & $31 *$ & 2.32 & 2.02 & 1.59 & 68 & 8.22 & 0.47 \\
\hline $\mathrm{pH}$ & 32 & 8.54 & 8.58 & 0.30 & 4 & 9.00 & 7.92 \\
\hline $\mathrm{CaCO}_{3}(\%)$ & $28 *$ & 2.95 & 2.60 & 1.42 & 48 & 7.21 & 1.66 \\
\hline $\mathrm{CEC}\left(\mathrm{cmol} \mathrm{Kg}{ }^{-1}\right)$ & $29 *$ & 12.2 & 10.6 & 5.5 & 45 & 19.9 & 4.7 \\
\hline Elect. Cond. $\left(\mu \mathrm{S} \mathrm{cm}^{-1}\right)$ & 32 & 146 & 139 & 63 & 43 & 364 & 25 \\
\hline
\end{tabular}

* The mass of $<100 \mu \mathrm{m}$ fraction was not large enough to complete all physico-chemical determinations

Table 3 Linear regression (assuming constant variance of residuals and zero bioaccessibility at zero total concentration) of SBET-, $\mathrm{HCl}$ - and RIVM- concentrations versus the aqua regia concentrations of each element (\%)

\begin{tabular}{|c|c|c|c|c|c|c|c|}
\hline & As & $\mathrm{Co}$ & $\mathrm{Cr}$ & $\mathrm{Cu}$ & $\mathrm{Ni}$ & $\mathrm{Pb}$ & $\mathrm{Zn}$ \\
\hline \multicolumn{8}{|l|}{ RIVM } \\
\hline Slope & 42 & 64 & 42 & 67 & - & 69 & 55 \\
\hline Confidence interval & $39-44$ & $59-68$ & $37-47$ & $61-73$ & - & $60-79$ & $51-59$ \\
\hline \multicolumn{8}{|l|}{ SBET } \\
\hline Slope & 63 & 26 & 6.2 & 47 & 18 & 59 & 56 \\
\hline Confidence interval & $58-68$ & $23-28$ & $4.4-8.1$ & $45-49$ & $15-20$ & $54-64$ & $51-60$ \\
\hline \multicolumn{8}{|l|}{$\mathrm{HCl}$} \\
\hline Slope & 52 & 28 & 8.5 & 55 & 18 & 57 & 61 \\
\hline Confidence interval & $49-55$ & $25-32$ & $6.8-10$ & $44-66$ & $14-22$ & $50-63$ & $53-69$ \\
\hline
\end{tabular}

half and a third of those values, with $\mathrm{Cr}$ showing the lowest percentage at around $7 \%$. Although it is difficult to compare these results with those of other studies elsewhere due to the large variability in extraction protocols, type of soil and grain size considered (Table 4), the indicated order of gastric bioaccessibility, that is, $\mathrm{As}=\mathrm{Cu}=\mathrm{Pb}=\mathrm{Zn}>$ $\mathrm{Co}>\mathrm{Ni}>\mathrm{Cr}$, remains remarkably similar.

However, the results of gastric + intestinal bioaccessibility followed the order $\mathrm{Co}=\mathrm{Cu}=\mathrm{Pb}>$ $\mathrm{Zn}=\mathrm{As}=\mathrm{Cr}$ and were consistently higher in this study than in those included in Table 4 except for As. Although this fact could be attributed to the $\mathrm{CaCO}_{3}$ rich nature of Madrid playground soils (see discussion below), it must be acknowledged that estimates of the RIVM method are not as reliable as those of the simplified, gastric protocols. This is not only because of the large number of unstable reactants involved in the extraction sequence but mostly because of the high (approximately tenfold) dilution. This can bring the analytical determinations near or below the detection limit if the soil is not highly contaminated as is the case in this study. A paired $t$ test of the results confirmed that As exhibited RIVM concentrations significantly lower than those in the SBET and $\mathrm{HCl}$ protocols, whilst $\mathrm{Co}, \mathrm{Cr}$ and $\mathrm{Cu}$ showed the opposite behaviour (for $\mathrm{Pb}$ and $\mathrm{Zn}$, the difference was not significant). These results are not easily reconciled with the fact 
Table 4 Comparison of gastric and gastric + intestinal bioaccessibility of trace elements in soil

\begin{tabular}{|c|c|c|c|c|c|c|c|c|c|c|c|c|c|c|c|}
\hline \multirow[t]{2}{*}{ Study } & \multicolumn{2}{|l|}{ As } & \multicolumn{2}{|l|}{$\mathrm{Cr}$} & \multicolumn{2}{|l|}{$\mathrm{Cu}$} & \multicolumn{2}{|l|}{$\mathrm{Ni}$} & \multicolumn{2}{|l|}{$\mathrm{Pb}$} & \multicolumn{2}{|l|}{$\mathrm{Zn}$} & \multirow{2}{*}{$\begin{array}{l}\text { Extraction } \\
\text { method }\end{array}$} & \multirow[t]{2}{*}{ Soil use/type } & \multirow{2}{*}{$\begin{array}{l}\text { Particle } \\
\text { size }\end{array}$} \\
\hline & Mean & $\begin{array}{l}\text { Range } \\
\text { (SD) }\end{array}$ & Mean & $\begin{array}{l}\text { Range } \\
\text { (SD) }\end{array}$ & Mean & $\begin{array}{l}\text { Range } \\
\text { (SD) }\end{array}$ & Mean & $\begin{array}{l}\text { Range } \\
\text { (SD) }\end{array}$ & Mean & $\begin{array}{l}\text { Range } \\
\text { (SD) }\end{array}$ & Mean & $\begin{array}{l}\text { Range } \\
\text { (SD) }\end{array}$ & & & \\
\hline \multicolumn{16}{|l|}{ Gastric } \\
\hline $\begin{array}{l}\text { Yang et al. } \\
(2002)\end{array}$ & 44 & $5.4-100$ & & & & & & & & & & & 5 & As-spiked & $<250 \mu \mathrm{m}$ \\
\hline $\begin{array}{l}\text { Juhasz et al. } \\
(2007)\end{array}$ & 34 & $6-89$ & & & & & & & & & & & 5 & Contaminated & $<250 \mu \mathrm{m}$ \\
\hline $\begin{array}{l}\text { Ellickson et al. } \\
\text { (2001) }\end{array}$ & 70 & $( \pm 8.3)$ & & & & & & & 76 & $( \pm 11)$ & & & 3 & NIST standard & $<74 \mu \mathrm{m}$ \\
\hline $\begin{array}{l}\text { Madrid et al. } \\
(2008)\end{array}$ & & & 2.6 & $1-6$ & 44 & $39-57$ & 12 & $8-14$ & 53 & $46-60$ & 40 & $34-43$ & 6 & $\begin{array}{l}\text { Urban } \\
\text { (Torino) }\end{array}$ & $<50 \mu \mathrm{m}$ \\
\hline $\begin{array}{l}\text { Madrid et al. } \\
(2008)\end{array}$ & & & 9 & $4-16$ & 20 & $13-24$ & 60 & $34-86$ & 39 & $30-51$ & 55 & $32-83$ & 6 & $\begin{array}{l}\text { Urban } \\
\text { (Seville) }\end{array}$ & $<50 \mu \mathrm{m}$ \\
\hline $\begin{array}{l}\text { Rasmussen et al. } \\
(2008)\end{array}$ & & & & & 32 & $( \pm 10)$ & 17 & $( \pm 7)$ & & & 29 & $( \pm 16)$ & 11 & Urban & $<150 \mu \mathrm{m}$ \\
\hline $\begin{array}{l}\text { Gbefa et al. } \\
\text { (2011) }\end{array}$ & & & 7 & & 14 & - & 8 & - & 5 & - & 12 & - & 8 & $\begin{array}{l}\text { BCR-Sewage } \\
\text { sludge }\end{array}$ & - \\
\hline $\begin{array}{l}\text { Poggio et al. } \\
(2009)\end{array}$ & & & & & 17 & $( \pm 1.4)$ & 4 & $( \pm 0.2)$ & 18 & $( \pm 1.2)$ & 43 & $( \pm 8.2)$ & 6,7 & Agricultural & $<2 \mathrm{~mm}$ \\
\hline $\begin{array}{l}\text { Poggio et al. } \\
\text { (2009) }\end{array}$ & & & & - & 15 & $( \pm 3.6)$ & 16 & $( \pm 2.0)$ & 20 & $( \pm 3.2)$ & 4 & $( \pm 0.4)$ & 6,7 & Urban & $<2 \mathrm{~mm}$ \\
\hline $\begin{array}{l}\text { Roussel et al. } \\
(2010)\end{array}$ & & & & & & & & & 62 & $33-76$ & 47 & $17-85$ & 1,2 & $\begin{array}{l}\text { Urban } \\
\text { contaminated }\end{array}$ & $<250 \mu \mathrm{m}$ \\
\hline $\begin{array}{l}\text { Luo et al. } \\
\text { (2012) }\end{array}$ & & & & & 17 & $( \pm 19)$ & & & 61 & $( \pm 52)$ & 68 & $( \pm 71)$ & 12 & Urban & $<150 \mu \mathrm{m}$ \\
\hline $\begin{array}{l}\text { Farmer et al. } \\
\text { (2011) }\end{array}$ & & & & & & & & & 52 & $( \pm 13)$ & & & 13 & Urban & $<250 \mu \mathrm{m}$ \\
\hline $\begin{array}{l}\text { Pelfrene et al. } \\
\text { (2012) }\end{array}$ & & & & & & & & & 58 & & 35 & & 14 & Contaminated & $<250 \mu \mathrm{m}$ \\
\hline $\begin{array}{l}\text { This study- } \\
\text { SBET }\end{array}$ & 62 & $( \pm 12.6)$ & 6.4 & $( \pm 4.2)$ & 46 & $( \pm 8.9)$ & 20 & $( \pm 7.5)$ & 59 & $( \pm 15.0)$ & 47 & $( \pm 14.0)$ & 6 & Playground & $<100 \mu \mathrm{m}$ \\
\hline This study $-\mathrm{HCl}$ & 53 & $( \pm 9.1)$ & 7.7 & $( \pm 4.1)$ & 47 & $( \pm 21)$ & 20 & $( \pm 11)$ & 52 & $( \pm 16.5)$ & 48 & $( \pm 18.37)$ & 10 & Playground & $<100 \mu \mathrm{m}$ \\
\hline \multicolumn{16}{|c|}{ Gastric + intestinal } \\
\hline $\begin{array}{l}\text { Ljung et al. } \\
\text { (2007) }\end{array}$ & 16 & - & 4.2 & & & & 3.9 & - & 4.2 & - & & & 1 & Playground & $<50 \mu \mathrm{m}$ \\
\hline $\begin{array}{l}\text { Ellickson et al. } \\
\text { (2001) }\end{array}$ & 65 & $( \pm 5.2)$ & & & & & & & 11 & $( \pm 2.3)$ & & & 3 & NIST standard & $<74 \mu \mathrm{m}$ \\
\hline $\begin{array}{l}\text { Carrizales et al. } \\
(2006)\end{array}$ & 46 & $39-66$ & & & & & & & 32 & $16-34$ & & & 4,5 & Contaminated & $<50 \mu \mathrm{m}$ \\
\hline
\end{tabular}


Table 4 continued

\begin{tabular}{|c|c|c|c|c|c|c|c|c|c|c|c|c|c|c|c|}
\hline \multirow[t]{2}{*}{ Study } & \multicolumn{2}{|l|}{ As } & \multicolumn{2}{|l|}{$\mathrm{Cr}$} & \multicolumn{2}{|l|}{$\mathrm{Cu}$} & \multicolumn{2}{|l|}{$\mathrm{Ni}$} & \multicolumn{2}{|l|}{$\mathrm{Pb}$} & \multicolumn{2}{|l|}{$\mathrm{Zn}$} & \multirow{2}{*}{$\begin{array}{l}\text { Extraction } \\
\text { method }\end{array}$} & \multirow[t]{2}{*}{ Soil use/type } & \multirow{2}{*}{$\begin{array}{l}\text { Particle } \\
\text { size }\end{array}$} \\
\hline & Mean & $\begin{array}{l}\text { Range } \\
\text { (SD) }\end{array}$ & Mean & $\begin{array}{l}\text { Range } \\
\text { (SD) }\end{array}$ & Mean & $\begin{array}{l}\text { Range } \\
\text { (SD) }\end{array}$ & Mean & $\begin{array}{l}\text { Range } \\
\text { (SD) }\end{array}$ & Mean & $\begin{array}{l}\text { Range } \\
\text { (SD) }\end{array}$ & Mean & $\begin{array}{l}\text { Range } \\
\text { (SD) }\end{array}$ & & & \\
\hline $\begin{array}{l}\text { Hamel et al. } \\
\text { (1998) }\end{array}$ & 67 & $( \pm 8)$ & & & & & & & & & & & 3 & Standard & $<74 \mu \mathrm{m}$ \\
\hline $\begin{array}{l}\text { Hamel et al. } \\
\text { (1999) }\end{array}$ & 41 & $( \pm 2)$ & 34 & $( \pm 14)$ & & & & & 39 & $( \pm 14)$ & & & 3 & Residential & $<125 \mu \mathrm{m}$ \\
\hline $\begin{array}{l}\text { Gbefa et al. } \\
\text { (2011) }\end{array}$ & & & 8 & - & 9 & - & 6 & - & 7 & - & 5 & - & 8 & BCR-Sewage sludge & - \\
\hline $\begin{array}{l}\text { Poggio et al. } \\
\text { (2009) }\end{array}$ & & & & & 31 & $( \pm 3.0)$ & 8 & $( \pm 0.4)$ & 5 & $( \pm 0.4)$ & 27 & $( \pm 4.6)$ & 6,7 & Agricultural & $<2 \mathrm{~mm}$ \\
\hline $\begin{array}{l}\text { Poggio et al. } \\
(2009)\end{array}$ & & & & & 4 & $( \pm 0.2)$ & 27 & $( \pm 6.7)$ & 8 & $( \pm 0.5)$ & 21 & $( \pm 6.1)$ & 6,7 & Urban & $<2 \mathrm{~mm}$ \\
\hline $\begin{array}{l}\text { Roussel et al. } \\
\text { (2010) }\end{array}$ & & & & & & & & & 32 & $14-63$ & 23 & $8-47$ & 1,2 & Urban contaminated & $<250 \mu \mathrm{m}$ \\
\hline $\begin{array}{l}\text { Farmer et al. } \\
\text { (2011) }\end{array}$ & & & & & & & & & 22 & $( \pm 9)$ & & & 13 & Urban & $<250 \mu \mathrm{m}$ \\
\hline $\begin{array}{l}\text { Pelfrene et al. } \\
\text { (2012) }\end{array}$ & & & & & & & & & 20 & & 10 & & 14 & Contaminated & $<250 \mu \mathrm{m}$ \\
\hline This study-RIVM & 43 & $( \pm 6.6)$ & 40 & $( \pm 18)$ & 61 & $( \pm 22.5)$ & & & 57 & $( \pm 30)$ & 46 & $( \pm 12)$ & 1 & Playground & $<100 \mu \mathrm{m}$ \\
\hline
\end{tabular}

1: Oomen et al. (2003)

2: Oomen et al. (2006)

3: Hamel et al. (1998, 1999)

4: Ruby et al. (1993)

5: Ruby et al. (1996)

6: Ruby et al. (1999)

7: Ruby (2004)

8: Dean (2010), Cave et al. (2002)

9: Juhasz et al. (2007)

10: Rasmussen et al. (2008)

11: European Committee for Standardization (1995)

12. Drexler and Brattin (2007)

13. Broadway et al. (2010)

14. Roussel et al. (2010) 
that raising the $\mathrm{pH}$ in the intestinal phase should cause: (a) partial precipitation and enhanced adsorption on mineral colloids and higher absorption in organic matter of cations (i.e. reduced bioaccessibility); and (b) desorption of As, the only trace element that should be present as an anion in the acidic gastric environment, from mineral surfaces and polar groups in organic matter as their density of positive charge decreases (i.e. increased bioaccessibility). Other authors have reported similarly unexpected results for $\mathrm{Cu}$ and $\mathrm{Ni}$ (Poggio et al. 2009) and have attributed the observed behaviour to the high affinity of the first two elements for glycine, and to metal binding competition between glycine and carbonates. For the weakly alkaline soils in this study, it is more likely that, as the $\mathrm{pH}$ is raised in the intestinal phase of the extraction procedure, there is competition with, and displacement of metal cations from available binding sites by the $\mathrm{Ca}$ ions previously released from calcium carbonate in the gastric stage. These arguments should be regarded with caution since, as was mentioned before, the reliability of the results of the RIVM procedure is questionable for uncontaminated soils, for which the analytical determinations often fall near the limit of detection of the method.

The influence of soil properties on the bioaccessibility of trace elements was evaluated by means of multiple linear regressions of: (a) the soil concentration of those elements extracted with the RIVM, SBET and $\mathrm{HCl}$ methods; and (b) the bioaccessibility ratios (i.e. RIVM:aqua regia, SBET:aqua regia and $\mathrm{HCl}$ :aqua regia) on a sub-set of predictor variables selected from the whole set of soil properties, including concentrations of major elements, using a Bayesian information criterion (BIC) analysis (Mingot et al. 2011).

The multiple linear regressions of gastric bioaccessibilty ratios on soil properties reveal that SBET extractable $\mathrm{Co}, \mathrm{Ni}$ and $\mathrm{Pb}$ are positively and significantly influenced by the organic matter content of the soil, whilst in the case of the $\mathrm{HCl}$ extraction, organic matter seems to influence significantly the bioaccessibility of $\mathrm{Cr}$, Ni and $\mathrm{Zn}$. Coupled with a strong positive correlation between organic matter and total (i.e. aqua regia) concentrations of these elements (except $\mathrm{Cr}$ ), this fact seems to indicate that as expected, soil organic matter effectively binds cations and that these cations become readily available in the strongly acidic environment of the SBET and $\mathrm{HCl}$ extracts. In the case of $\mathrm{Cr}$, binding to organic matter does not seem to be a very efficient retention mechanism (indicated by a very weak correlation with aqua regia $\mathrm{Cr}$ concentrations). The little $\mathrm{Cr}$ that is fixed by the polar groups of natural organic matter is again easily released in the gastric environment, as revealed by the highly significant correlation coefficients between SBET and $\mathrm{HCl}$ bioaccessible concentrations and organic matter and corroborated by the significant influence of organic matter in the linear model for the SBET:aqua regia bioaccessibility ratio.

The influence of $\mathrm{pH}$ on the bioaccessible concentrations of trace elements in Madrid playground soil is not as critical as in other studies. This is very likely a consequence of the very low variability of $\mathrm{pH}$ in the samples collected in Madrid. Nevertheless, the gastric bioaccessibility of $\mathrm{Cr}$, and to a lesser extent $\mathrm{Ni}$, especially as estimated in the SBET, does seem to be strongly controlled by soil $\mathrm{pH}$, both in absolute terms and relative to the total $\mathrm{Cr}$ concentration in the soil. Chromium is present in urban soil mostly as residual minerals (Poggio et al. 2009), most likely mixed $\mathrm{Cr}^{3+}$ and $\mathrm{Fe}^{3+}$ oxides (Kabata-Pendias and Pendias 1992). As previously discussed, a small fraction, however, is retained in the form of organic complexes, which readily release $\mathrm{Cr}$ in the gastric solution, hence the highly significant correlation coefficient between organic matter and bioaccessible $\mathrm{Cr}$. The role that soil $\mathrm{pH}$ plays as a controlling factor of $\mathrm{Cr}$ bioaccessibility is probably related to the redox behaviour of this element in alkaline soils. At $\mathrm{pH}$ values around 8.5, small deviations towards higher values would promote the occurrence of $\mathrm{Cr}$ in soluble $\mathrm{Cr}^{6+}$ forms that would be removed from the surficial soil matrix. Correspondingly, small drops in $\mathrm{pH}$ in the presence of organic matter would facilitate the formation of those $\mathrm{Cr}$ (III) complexes previously discussed which constitute the bioaccessible fraction of this element.

Total $\mathrm{Fe}$ is positively correlated with the aqua regia concentration of all trace elements analysed except $\mathrm{Cr}$, a fact that lends support to the idea that a fraction of the $\mathrm{Fe}$ oxides in the weakly alkaline soils of Madrid retain a negative surface charge at $\mathrm{pH} 8.5$ and act as a retention medium for cations. In terms of gastric bioaccessibility, the multiple linear regressions show that the bioaccessibility ratios of all trace elements decrease as the concentration of $\mathrm{Fe}$ increases in the sample (and once the influence of the other variables have been discounted). This could be a consequence of the formation of very stable metal chloride complexes 
in the $\mathrm{Cl}^{-}$-rich, acidic solution used to simulate the gastric environment. These complexes carry overall negative charge and would be removed from solution and fixed to the positive surface charges developed by the Fe oxides at this low pH (Adriano 2001) therefore lowering the bioaccessibility of metal ions.

As opposed to cations, the behaviour of As seems to be mainly controlled by the $\mathrm{Ca}$ content of the soil (Mingot et al. 2011). Most of the total load of As in Madrid's samples appears to be bound to carbonate surfaces and maybe also present as $\mathrm{Ca}$ As precipitates. This As is readily dissolved and made bioaccessible in the low-pH gastric extracts, hence the high values of $\mathrm{HCl}$ As and specially SBET As. Organic matter does not contribute significantly to the overall As content in the playground soil of Madrid but the small fraction of As bound to humic substances most likely through $\mathrm{Ca}$ bridges is released in the gastric and gastro-intestinal environments (Mingot et al. 2011). Conversely, the little As bound to the Fe oxides in Madrid's playgrounds is not released during the gastric extraction, as manifested in the significant, negative partial correlation between all three modes of bioaccessible As and Fe.

\section{Conclusions}

The gastric bioaccessibility of trace elements in the playground soils included in this study follows the order: $\mathrm{As}=\mathrm{Cu}=\mathrm{Pb}=\mathrm{Zn}>\mathrm{Co}>\mathrm{Ni}>\mathrm{Cr}$. In terms of the implications for risk assessment, in which aqua regia or "total" concentrations are generally used, comparison with bioaccessibility values reveals that total concentrations for $\mathrm{As}, \mathrm{Cu}, \mathrm{Pb}$, and $\mathrm{Zn}$ in the soil was double, whereas that for $\mathrm{Cr}$ was more than one order of magnitude higher. The results of the SBET and the $\mathrm{HCl}$ protocols are very similar for most metals. Gastric bioaccessibility can be estimated by either method without any appreciable difference except for As, for which SBET concentrations are significantly higher, and for $\mathrm{Cr}$, which shows the opposite behaviour.

The RIVM method reveals that the gastric + intestinal bioaccessibilities of the trace elements analysed follow the order: $\mathrm{Co}=\mathrm{Cu}=\mathrm{Pb}>\mathrm{Zn}=\mathrm{Cr}=\mathrm{As}$ are higher than the corresponding gastric values for $\mathrm{Co}, \mathrm{Cu}$ and $\mathrm{Cr}$, and higher than the results arrived at by other researchers (see Table 4) except for As. These unexpected high values of gastric + intestinal bioaccessibility could be explained by the preferential binding of previously released $\mathrm{Ca}$ ions and displacement of trace elements from exchange sites in the intestinal phase of the extraction protocol. The RIVM method is complex, involving a large number of unstable reactants and high dilutions, and its results in this study should be interpreted with caution. Despite these complications, relative to gastric-only extraction procedures, the RIVM method or later adaptations there of (the Unified BARGE Method, Wragg et al. 2011) should yield results that more closely approximate in vivo bioaccessibilities.

Different soil properties seem to dictate the behaviour of the different elements in terms of their bioaccessibility. In weakly alkaline, organic matter and $\mathrm{Fe}$ deficient, urban soils $\mathrm{Cu}, \mathrm{Pb}$ and $\mathrm{Zn}$ are predominantly bound to organic matter and, to a lesser extent, Fe oxides. Whereas the fraction of those elements originally associated with soil organic matter is readily accessible in the gastric solution, Fe oxides seem to recapture and therefore lower the bioaccessibility of $\mathrm{Cu}, \mathrm{Pb}$ and $\mathrm{Zn}$ in the form of negatively charged chloride complexes of these elements. Chromium is present primarily in the residual fraction of playground soil and therefore very little is bioaccessible, the small percentage of which is associated with soil organic matter. The occurrence of these organometallic complexes seems to be strongly $\mathrm{pH}$ dependent, and the amount of $\mathrm{Cr}$ thus retained appears to increase significantly with only minor $\mathrm{pH}$ reductions. Arsenic presents a very different behaviour from that of the other trace elements, in that it is most likely associated with calcium carbonate. The high bioaccessibility of As is a consequence of the ease with which its bonds to carbonate surfaces are broken under the strongly acidic conditions of the gastric solution.

The results of this study clearly demonstrate the influence of soil properties on the bioaccessibility of trace elements in playground soil and highlight the need to determine and understand these properties in order to properly interpret variations of bioaccessibility among different elements and different soils. As a consequence, the modes of retention in the soil and release in the gastric solution that have been discussed for Madrid playgrounds may not be directly applied to other environments and other extraction protocols.

Acknowledgments The authors are deeply indebted to the Laboratorio Arbitral Agroalimentario de Madrid (Spanish Ministry of Agriculture, Food and Environment) for the ICPMS analyses of the RIVM, SBET and $\mathrm{HCl}$ extracts. The authors would also like to express their gratitude to Dr. Alex G. Stewart 
(Cheshire \& Merseyside Health Protection Unit) and two anonymous reviewers for their comments and suggestions which have helped to improve this manuscript significantly.

\section{References}

Adriano, D. C. (2001). Trace elements in terrestrial environments, biogeochemistry, bioavailability and the risks of metals (2nd ed.). New York: Springer.

Allison, L. E., \& Moodie, C. D. (1965). Carbonate. In C.A. Black et al. (eds.), Methods of soil analysis. Part 2,2nd edn (pp. 1379-1400). Agron. Monogr. 9. Madison, Wisconsin: ASA, CSSA, and SSSA.

Bower, C. A., Reitemeier, R. F., \& Fireman, M. (1952). Exchangeable cation analysis of saline and alkali soils. Soil Science, 73, 251-261.

Broadway, A., Cave, M. R., Wragg, J., Fordyce, F. M., Bewley, R. J. F., Graham, M. C., et al. (2010). Determination of the bioaccessibility of chromium in Glasgow soil and the implications for human health risk assessment. Science of the Total Environment, 409, 267-277.

Carrizales, L., Razo, I., Téllez-Hernández, J., Torres-Nerio, T., Torres, A., Batres, L., et al. (2006). Exposure to arsenic and lead of children living near a copper-smelter in San Luis Potosi, Mexico: Importance of soil contamination for exposure of children. Environmental Research, 101, $1-10$.

Cave, M. R., Wragg, J., Palumbo, B., \& Klinck, B. A. (2002). Measurement of the bioaccessibility of arsenic in UK soils. British Geological Survey and Environment Agency $R \& D$ Technical Report P5-062/TR02. Bristol: Environment Agency.

De Miguel, E., Callaba, A., Arranz, J., Cala, V., Chacón, E., \& Gallego, E. et al. (2002). Determinación de niveles de fondo y niveles de referencia de metales pesados y otros elementos traza en suelos de la Comunidad de Madrid. Madrid Instituto Geológico y Minero de España (in Spanish).

De Miguel, E., Iribarren, I., Chacón, E., Ordoñez, A., \& Charlesworth, S. (2007). Risk-based evaluation of the exposure of children to trace elements in playgrounds in Madrid Spain. Chemosphere, 66, 505-513.

Dean, J. (2010). Bioavailability, bioaccessibility and mobility of environmental contaminants. Chichester: Wiley.

Drexler, J. W., \& Brattin, W. J. (2007). An in vitro procedure for estimation of lead relative bioavailability: With validation. Human and Ecological Risk Assessment, 13, 383-401.

Dudka, S., \& Miller, W. P. (1999). Permissible concentrations of arsenic and lead in soils based on risk assessment. Water, Air, and Soil pollution, 113, 127-132.

Ellickson, K. M., Meeker, R. J., Gallo, M. A., Buckley, B. T., \& Lioy, P. J. (2001). Oral bioavailability of lead and arsenic from a NIST standard reference soil material. Archives of Environmental Contamination and Toxicology, 40, 128-135.

European Committee for Standardization (1995). EN-71: Safety of toys-Part 3: Specification for migration of certain elements. British Standard EN 71-3. European Committee for Standardization, 2001. Impact absorbing playground surfacing. Safety Requirements and Test Methods. EN 1177:1997/A1.
Farmer, J. G., Broadway, A., Cave, M. R., Wragg, J., Fordyce, F. M., Graham, M. C., et al. (2011). A lead isotopic study of the human bioaccessibility of lead in urban soils from Glasgow, Scotland. Science of the Total Environment, 409, 4958-4965.

Gbefa, B., Entwistle, J., \& Dean, J. (2011). Oral bioaccessibility of metals in an urban catchment, Newcastle upon Tyne. Environmental Geochemistry and Health, 33, 167-181.

Hamel, S. C., Buckley, B., \& Lioy, P. J. (1998). Bioaccessibility of metals in soils for different liquid to solid ratios in synthetic gastric fluid. Environmental Science and Technology, 323, 358-362.

Hamel, S. C., Ellickson, K. M., \& Lioy, P. J. (1999). The estimation of the bioaccessibility of heavy metals in soils using artificial biofluids by two novel methods: Mass balance and soil recapture. Science of the Total Environment, 243-244, 273-283.

Juhasz, A. L., Smith, E., Weber, J., Rees, M., Rofe, A., Kuchel, T., et al. (2007). In vitro assessment of arsenic bioaccessibility in contaminated anthropogenic and geogenic soils. Chemosphere, 69, 69-78.

Kabata-Pendias, A., \& Pendias, H. (1992). Trace elements in soils and plants. Boca Raton, FL: CRC Press.

Ljung, K., Oomen, A., Duits, M., Selinus, O., \& Berglund, M. (2007). Bioaccessibility of metals in urban playground soils. Journal of Environmental Science and Health, 42, 1241-1250.

Luo, X-s., Yu, S., \& Li, X-d. (2012). The mobility, bioavailability, and human bioaccessibility of trace metals in urban soils of Hong Kong. Applied Geochemistry, 27, 995-1004.

Madrid, F., Biasioli, M., \& Ajmone-Marsan, F. (2008). Availability and bioaccessibility of metals in fine particles of some urban soils. Archives of Environmental Contamination and Toxicology, 55, 21-32.

Mingot, J., De Miguel, E., \& Chacón, E. (2011). Assessment of oral bioaccessibility of Arsenic in playground soil in Madrid (Spain). A three-method comparison and implications for risk assessment. Chemosphere, 84, 1386-1391.

Oomen, A. G., Brandon, E. F. A., Swartjes, F. A., \& Sips, A. J. A. M. (2006). How can information on oral bioavailability improve human health risk assessment for leadcontaminated soils? RIVM report 711701042/2006.

Oomen, A. G., Rompelberg, C. J. M., Bruil, M. A., Dobbe, C. J. G., Pereboom, D. P. K. H., \& Sips, A. J. A. M. (2003). Development of an in vitro digestion model for estimation of bioaccessibility of soil contaminants. Archives of Environmental Contamination and Toxicology, 44, 281-287.

Pelfrêne, A., Waterlot, C., Mazzuca, M., Nisse, C., Cuny, D., Richard, A., et al. (2012). Bioaccessibility of trace elements as affected by soil parameters in smelter-contaminated agricultural soils: A statistical modeling approach. Environmental Pollution, 160, 130-138.

Poggio, L., Vrscaj, B., Schulin, R., Hepperle, E., \& Ajmone Marsan, F. (2009). Metal pollution and human bioaccessibility of topsoils in Grugliasco (Italy). Environmental Pollution, 157, 680-689.

Rasmussen, P. E., Beauchemin, S., Nugent, M., Dugandzic, R., Lanouette, M., \& Chénier, M. (2008). Influence of matrix composition on the bioaccessibility of Copper, Zinc, and Nickel in urban residential dust and soil. Human and Ecological Risk Assessment, 14, 351-371. 
Roussel, H., Waterlot, C., Pelfrene, A., Pruvot, C., Mazzuca, M., \& Douay, F. (2010). Cd, Pb and $\mathrm{Zn}$ oral bioaccessibility of urban soils contaminated in the past by atmospheric emissions from two lead and zinc smelters. Archives of Environmental Contamination and Toxicology, 58, 945-954.

Ruby, M. V. (2004). Bioavailability of soil-borne chemicals: Abiotic assessment tools. Human and Ecological Risk Assessment, 10, 647-656.

Ruby, M. V., Davis, A., Link, T. E., Schoof, R., Chaney, R. L., Freeman, G. B., et al. (1993). Development of an in vitro screening test to evaluate the in vivo bioaccessibility of ingested mine-waste lead. Environmental Science and Technology, 27, 2870-2877.

Ruby, M. V., Davis, A., Schoof, R., Eberle, S., \& Sellstone, C. M. (1996). Estimation of lead and arsenic bioavailability using a physiologically based extraction test. Environmental Science and Technology, 30, 422-430.

Ruby, M. V., Schoof, R., Brattin, W., Goldade, M., Post, G., Harnois, M., et al. (1999). Advances in evaluating the oral bioavailability of inorganics in soil for use in human health risk assessment. Environmental Science and Technology, $33,3697-3705$.

$\mathrm{R}$ Development Core Team (2004). $R$ : A language and environment for statistical computing, $R$ Foundation for Statistical Computing. <http://www.Rproject.org>.
Tseng, W. P. (1977). Effects and dose-response relationships of skin cancer and blackfoot disease with arsenic. Environmental Health Perspectives, 19, 109-119.

Tseng, W. P., Chu, H. M., How, S. W., Fong, J. M., Lin, C. S., \& Yeh, S. (1968). Prevalence of skin cancer in an endemic area of chronic arsenicism in Taiwan. Joumal of the National Cancer Institute, 40, 453-463.

USEPA (2011). Integrated risk information system IRIS. <http:// www.epa.gov/ncea/iris/subst/0278.htm>.

Walkley, A. (1935). An examination of methods for determining organic carbon and nitrogen in soils. Joumal of Agricultural Science, 25, 598-609.

Wragg, J., Cave, M., Basta, N., Brandon, E., Casteel, S., Denys, S., et al. (2011). An inter-laboratory trial of the unified BARGE bioaccessibility method for arsenic, cadmium and lead in soil. Science of the Total Environment, 409, 4016-4030.

Yang, J., Barnett, M. O., Jardine, P. M., Basta, N. T., \& Casteel, S. W. (2002). Adsorption, sequestration, and bioaccessibility of $\mathrm{As}(\mathrm{V})$ in soils. Environmental Science and Technology, 36, 4562-4569.

Zhang, J., \& Li, X. (1987). Chromium pollution of soil and water in Jinzhou. Journal of Chinese Preventive Medicine, 21, 262-264. 